\title{
Differences in postperinatal infant deaths between North and Southern Derbyshire
}

\author{
Mary Newlands, Elizabeth Adamson, Sara Ghulam, Mohammed Saleh, John L Emery
}

\begin{abstract}
In depth confidential inquiries on all postperinatal infant deaths were carried out for two years in North and Southern Derbyshire District Health Authorities in order to explore why the postperinatal death rates and cot death rates have been consistently higher in Southern than in North Derbyshire.

It was found that the death rates for probably inevitable deaths and for 'idiopathic' cot deaths were the same in both districts. The differences in the death rates lay in the group of partly explained cot deaths. Adverse social factors associated with each death were recorded and an estimate made of their relevance to the individual deaths. The group of deaths most amenable to intervention was those of category B (partly explained cot deaths). As judged by the Jarman index there are more areas of deprivation in Southern than in North Derbyshire.
\end{abstract}

Over the past decade the postperinatal infant mortality rates in the Southern Derbyshire Health Authority have exceeded national and regional averages while those in the North Derbyshire Health Authority have remained consistently below the national averages. Two studies failed to explain this finding. First, a working party was set up in 1978 to find out if there were shortfalls in hospital or community services that could have contributed to the high mortality rate within the area. The second investigation involved participation of Southern Derbyshire in the Trent Regional Confidential Enquiry into Infant Mortality during $1984 .^{1}$ This inquiry produced information, on individual case inquiry, particularly suggesting the presence of social and service defects but at insufficient depth for action.

Subsequently, analysis of data relating to infant mortality in Southern Derbyshire between 1975 and 1988 was undertaken. A relative rise in children registered as cot death was revealed and the differences between North

Table 1 Categories of preventability by clinicopathological diagnosis

\begin{tabular}{|c|c|}
\hline Category & Diagnosis \\
\hline A & $\begin{array}{l}\text { Conditions with poor prognosis where deaths are apparently inevitable with the } \\
\text { present knowledge and facilities }\end{array}$ \\
\hline B & $\begin{array}{l}\text { Partially treatable condition present either as a major cause or possible contributing } \\
\text { factor to death. Treatable diagnosable conditions under ideal circumstances }\end{array}$ \\
\hline $\begin{array}{l}\text { C } \\
\text { D } \\
\text { E }\end{array}$ & $\begin{array}{l}\text { Death during the course of a minor condition not normally requiring treatment } \\
\text { No terminal illness reported. No clinical findings. 'Idiopathic' cot death } \\
\text { Accidental death }\end{array}$ \\
\hline $\mathbf{F}$ & $\begin{array}{l}\text { Accidental death } \\
\text { Non-accidental death: } \\
\text { (a) Proved non-accidental injury } \\
\text { (b) Parental action is a possibly major contributory factor }\end{array}$ \\
\hline G & Insufficient information for categorisation into one of the above groups \\
\hline
\end{tabular}

and Southern Derbyshire were still obvious. In $\overline{\bar{c}}$ 1987 a system of confidential inquiry into each $\vec{\odot}$ postperinatal death was incorporated into routine services as part of an ongoing process ${ }^{\infty}$ audit in Southern Derbyshire. North Derbyshire $\vec{\circ}$ did a parallel study of confidential inquiry to $\overrightarrow{\vec{\omega}}$ investigate differences in infant mortality $\stackrel{\omega}{\mathcal{D}}$ between the two health districts under standard conditions over a period of two years, 1987/8.? The aims of the study were to compare deaths? according to categories of preventability in each $\vec{N}$ health district and to relate each death with $\vec{A}$ home, psychological, and social factors that $\stackrel{\sim}{\sim}$ might have had a major impact on the circum-응 stances leading to death.

\section{Methods}

The confidential inquiry on all postperinatal deaths involved a study of all casenotes (obstetric,,$\vec{\oplus}$ health visitor, hospital, and family doctor), a $\Theta$ home visit by a senior health professional, and $\mathrm{a}^{-}$ conference in the family doctor's office. The inquiry was carried out by persons not directly concerned with the care of any of the families. This method of inquiry was based on the Sheffield model $^{2}$ and, to ensure comparability $\triangle$ in the study of the districts, a senior clinical $\vec{\circ}$ medical officer (EA) acted as an independent ${ }^{3}$ observer at all case discussions in both districts. Each district had a coordinating doctor.

The questionnaires used were those devised in Sheffield with the addition of a locally? devised one for social services inquiry. Post- -3 mortem reports were obtained and all of the home interviews were carried out by a senior 3 health professional not concerned with the ${ }_{\circ}$ direct care of the child or family. After collation of all information case conferences wereo arranged, usually in the general practitioner's surgery. Core members of these conferences $\sigma$ were: general practitioner, health visitor, home $N$ interviewer, coordinating doctor, and observing $N$ doctor. All available information concerningo adverse health and social factors in the baby'so history was collated, the final classification $\mathscr{\mathbb { D }}^{\circ}$ being made at or immediately after the case? discussion. The deaths were classified as in the Sheffield studies (see table 1). ${ }^{3}$ Category $A \stackrel{\odot}{\oplus}$ deaths are probably inevitable after birth.

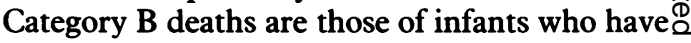
disease which, if treated, may have influenced the fatal outcome. Category $\mathrm{C}$ deaths are those of infants with minor disease unlikely to have been related to the fatal outcome. Category $\mathrm{D}_{0}$ deaths are essentially idiopathic with no identified disease on full postmortem examination. Finally category $\mathbf{E}$ deaths are accidental, $\mathrm{F}$ are 
probable or proved filicide, and $G$ are those where there is insufficient information for categorisation. A judgment was then made as to the possible preventability or otherwise of the death. At the end of the two year study all notes were reviewed and the $A-G$ classification verified. In each case a listing of all the recorded adverse factors mitigating against the child was made. A further classification was then made as to preventability after birth in the following categories: inevitable, probably inevitable, possibly preventable, probably preventable, and don't know.

\section{Results}

During the years under study there were 8802 live births in North and 14241 in Southern Derbyshire. In North Derbyshire there were 42 postperinatal infant deaths with 18 presenting as cot deaths, and in Southern Derbyshire there were 87 deaths with 47 presenting as cot deaths (see table 2). In Southern Derbyshire there were nine children where there was insufficient information to fully categorise the deaths. In the north there were no such cases. When unexpected home deaths were broken down into their A-G subgroups differences emerged between the two districts (table 2).

The total postperinatal death rate in North Derbyshire was 4.77 compared with that of 6.1/1000 live births in Southern Derbyshire. When the category $A$ deaths (the probably nonpreventable deaths) were considered there was very little difference between the districts $(2 \cdot 27$ and $2 \cdot 45 / 1000$ live births). The difference in the total rates was largely due to the lower rate of category B deaths in the North 0.46 compared with $1 \cdot 3 / 1000$ births in Southern Derbyshire. These differences were further emphasised when the deaths were divided into babies presenting as unexpected home deaths and others, the profiles of the unexpected deaths

Table 2 Postperinatal deaths in north and southern Derbyshire 1987 and 1988

\begin{tabular}{lll}
\hline & $\begin{array}{l}\text { North } \\
\text { Derbyshire }\end{array}$ & $\begin{array}{l}\text { Southern } \\
\text { Derbyshire }\end{array}$ \\
\hline Births & 8802 & 14241 \\
Deaths (rate/1000 live births) & $42(4 \cdot 77)$ & $87(6 \cdot 10)$ \\
Cot death (rate/1000 live births) & $18(2 \cdot 04)$ & $47(3 \cdot 30)$ \\
Total deaths (rate/1000 live births) & \\
by category: & $20(2 \cdot 27)$ & $35(2 \cdot 45)$ \\
A & $4(0 \cdot 46)$ & $19(1 \cdot 3)$ \\
B & $2(0 \cdot 23)$ & $9(0 \cdot 63)$ \\
C & $8(0 \cdot 9)$ & $6(0 \cdot 42)$ \\
D & $3(0 \cdot 34)$ & $1(0 \cdot 07)$ \\
E & $5(0 \cdot 57)$ & $8(0 \cdot 56)$ \\
F & 0 & $9(0 \cdot 63)$ \\
G & \\
No (\%) unexpected home deaths & $($ cot deaths) & \\
by category: & 0 & $1(2)$ \\
A & 0 & $16(34)$ \\
B & $3(17)$ & $9(19)$ \\
C & $2(11)$ & $6(13)$ \\
D & $8(44)$ & $1(2)$ \\
E & $2(11)$ & $6(13)$ \\
F & $3(17)$ & $8(17)$ \\
G & 0 & $47(100)$ \\
Total & $18(100)$ & \\
No (\%) other deaths by category: & & \\
A & $20(83)$ & $34(85)$ \\
B & $1(4)$ & $3(8)$ \\
C & 0 & 0 \\
D & 0 & 0 \\
E & $1(4)$ & 0 \\
F & $2(8)$ & $2(5)$ \\
G & 0 & $1(3)$ \\
Total & $24(100)$ & $40(100)$ \\
\hline & & \\
\hline & & \\
\hline
\end{tabular}

being clearly different in the two districts while those of the other deaths are very similar.

\section{ADVERSE SOCIAL FACTORS}

The factors mitigating against a child were analysed under 34 headings grouped into 12 sections (table 3 ). These were also related to the clinical groupings on the A-G scale. Medical factors were confined to deaths in categories $A$ and $B$, these being the only deaths that had had medical involvement. There were six children where there was delay in medical treatment. Non-cooperation with medical services was seen in all groups of death except in group $A$. Inexperienced parenting predominated in the category $F$ deaths while defective modelling for parenting was evenly distributed among the different categories. Heavy drinking and smoking by parents was associated with category $\mathrm{D}$ deaths, which also contained one of the three families that were on drugs. The unsupported mother was the commonest factor identified in the study, occurring in 29 of 129 families but in only one category $A$ death. The history of overdose of a parent was present in one of the category $A$ deaths and five of the other deaths. Depression and possible psychological disturbance was important, the greatest prevalence being in the category $F$ group. Poor housing was common in all categories.

The same applied to family financial problems where debts had accumulated, the commonest being rent arrears and problems with heating bills. These families were not always found in the unemployed category. The number of families out of work in this series was remarkably small. Poor bonding was a joint subjective judgment made by the health visitor, midwife and/or the general practitioner made at the case conference based on their observations of the mother and child during life. This was an assessment of situations where the mother's attitude to the child had been ambivalent or her handling of the child had been inappropriate to that expected. The features emerged only at case conference and had not been recorded on the routine child records. In this group half of the cases came under category $F$, which was the category that included the only cases where there had been a previous cot death in the family. Social service involvement was prevalent in the category $B$ and $F$ groups. The presence of twins, four baby deaths, appeared to be only associated with the cot death categories of $\mathrm{C}$ and $\mathrm{D}$.

The number of adverse factors/case (the adverse factors:case ratio) was worked out for each district and for each category of death (table 4). In group A babies there were 0.29 factors/case compared with an average of $2 \cdot 7$ for all the other categories. In categories B, E, and $F$ the adverse factor case ratio was higher in Southern than in North Derbyshire, the greatest concentration of factors being in categories $\mathrm{E}$ and $F$.

PREVENTABILITY

In the final review of each case an assessment 
Table 3 Adverse social factors related to category of death $(A-G)$

\begin{tabular}{|c|c|c|c|c|c|c|c|c|}
\hline Factor & $\underset{(n=55)}{A}$ & $\underset{(n=23)}{B}$ & $\underset{(n=11)}{C}$ & $\underset{(n=14)}{D}$ & $\begin{array}{l}E \\
(n=4)\end{array}$ & $\begin{array}{l}F \\
(n=13)\end{array}$ & $\begin{array}{l}G \\
(n=9)\end{array}$ & $\begin{array}{l}\text { Total } \\
(n=129)\end{array}$ \\
\hline $\begin{array}{l}\text { Communication defects: } \\
\text { (1) Hospital to home } \\
\text { (2) General practitioner to hospital } \\
\text { (3) Hospital to home } \\
\text { (4) Home to hospital }\end{array}$ & $\begin{array}{l}3 \\
1\end{array}$ & $\begin{array}{l}2 \\
1 \\
6\end{array}$ & & & & & & $\begin{array}{l}5 \\
1 \\
1 \\
6\end{array}$ \\
\hline (5) Non-cooperation with medical services & & 2 & 2 & 2 & 1 & 3 & 2 & 12 \\
\hline $\begin{array}{l}\text { (6) Very inexperienced parents or low IQ } \\
\text { (7) Parents low/defective standard of health } \\
\text { (8) In care as a child (broken home): mothe } \\
\text { (9) In care as a child (broken home): father }\end{array}$ & 1 & $\begin{array}{l}2 \\
3 \\
2\end{array}$ & $\frac{1}{3}$ & 1 & $\begin{array}{l}2 \\
1 \\
1\end{array}$ & $\begin{array}{l}6 \\
2 \\
2 \\
1\end{array}$ & $\begin{array}{l}2 \\
0\end{array}$ & $\begin{array}{r}14 \\
8 \\
6 \\
3\end{array}$ \\
\hline $\begin{array}{l}\text { (10) Heavy drinker (either parent) } \\
\text { (11) Heavy smoker (either parent) } \\
\text { (12) On drugs }\end{array}$ & & 1 & $\frac{1}{2}$ & $\begin{array}{l}4 \\
5 \\
1\end{array}$ & 1 & $\frac{1}{2}$ & $\begin{array}{l}1 \\
1\end{array}$ & $\begin{array}{r}7 \\
10 \\
3\end{array}$ \\
\hline $\begin{array}{l}\text { (13) Single unsupported mother } \\
\text { (14) Cohabiting unsupported mother }\end{array}$ & 1 & $\begin{array}{l}5 \\
4\end{array}$ & 4 & $\frac{1}{3}$ & 2 & 5 & 1 & $\begin{array}{l}15 \\
14\end{array}$ \\
\hline $\begin{array}{l}\text { Mother: } \\
\text { (15) Depressed/anxious } \\
\text { (16) Personality disturbance } \\
\text { (17) Overdose or other method } \\
\text { (18) Has been seeing psychiatrist } \\
\text { Father: } \\
\text { (19) Depressed/anxious } \\
\text { (20) Personality disturbance } \\
\text { (21) Overdose or other method } \\
\text { (22) Has been seeing psychiatrist }\end{array}$ & 1 & $\begin{array}{l}3 \\
1 \\
1\end{array}$ & 2 & 2 & & $\begin{array}{l}1 \\
2 \\
2 \\
2 \\
1 \\
1 \\
1\end{array}$ & 1 & $\begin{array}{l}1 \\
1 \\
2 \\
1\end{array}$ \\
\hline $\begin{array}{l}\text { (23) Stress acute } \\
\text { (24) Stress chronic (chronic illness) }\end{array}$ & 1 & $\frac{1}{2}$ & 3 & 2 & & & 1 & $\begin{array}{l}4 \\
7\end{array}$ \\
\hline $\begin{array}{l}\text { (25) Poor housing } \\
\text { (26) Financial problems } \\
\text { (27) Out of work }\end{array}$ & $\begin{array}{l}4 \\
2\end{array}$ & $\begin{array}{l}5 \\
1 \\
1\end{array}$ & $\begin{array}{l}2 \\
1 \\
1\end{array}$ & $\begin{array}{l}0 \\
4 \\
0\end{array}$ & & 2 & $\begin{array}{l}2 \\
2\end{array}$ & $\begin{array}{r}15 \\
11 \\
4\end{array}$ \\
\hline (28) Poor bonding & & 1 & 1 & & & 3 & 1 & 6 \\
\hline $\begin{array}{l}\text { (29) Family involved with police } \\
\text { (30) Social service involvement as } \\
\text { problem family }\end{array}$ & 1 & $\frac{1}{2}$ & $\begin{array}{l}1 \\
1\end{array}$ & $\begin{array}{l}0 \\
2\end{array}$ & 1 & $\begin{array}{l}3 \\
4\end{array}$ & $\begin{array}{l}1 \\
1\end{array}$ & $\begin{array}{r}7 \\
11\end{array}$ \\
\hline $\begin{array}{l}\text { (31) Member of family on register for } \\
\text { non-accidental injury } \\
\text { (32) Violent household }\end{array}$ & & $\begin{array}{l}2 \\
1\end{array}$ & 1 & 1 & 1 & $\begin{array}{l}2 \\
5\end{array}$ & 2 & 10 \\
\hline (33) Twin & & & 2 & 2 & & & & 4 \\
\hline (34) Previous cot death & & & & & & 3 & & 3 \\
\hline
\end{tabular}

Table 4 Presence of all adverse family and social factors present in North and Southern Derbyshire related to category of death $(A-G)$

\begin{tabular}{|c|c|c|c|c|c|c|c|c|c|}
\hline \multirow[t]{2}{*}{ Category } & \multicolumn{3}{|c|}{ North Derbyshire } & \multicolumn{3}{|c|}{ Southern Derbyshire } & \multicolumn{3}{|c|}{ North and Southern Derbyshire combined } \\
\hline & Total & $\begin{array}{l}\text { Adverse } \\
\text { factors }\end{array}$ & $\begin{array}{l}\text { Adverse } \\
\text { factors:case } \\
\text { ratio }\end{array}$ & Total & $\begin{array}{l}\text { Adverse } \\
\text { factors }\end{array}$ & $\begin{array}{l}\text { Adverse } \\
\text { factors:case } \\
\text { ratio }\end{array}$ & Total & $\begin{array}{l}\text { Adverse } \\
\text { factors }\end{array}$ & $\begin{array}{l}\text { Adverse } \\
\text { factors:case } \\
\text { ratio }\end{array}$ \\
\hline $\begin{array}{l}\text { A } \\
\text { B } \\
\text { C } \\
\text { D } \\
\text { E } \\
\text { F } \\
\text { G } \\
\text { Total B-G }\end{array}$ & $\begin{array}{r}20 \\
4 \\
2 \\
8 \\
3 \\
5 \\
0 \\
22\end{array}$ & $\begin{array}{r}7 \\
7 \\
4 \\
21 \\
3 \\
17 \\
0 \\
52\end{array}$ & $\begin{array}{l}0.35 \\
1 \cdot 7 \\
2 \cdot 0 \\
2 \cdot 6 \\
1.0 \\
3 \cdot 4 \\
0 \\
2 \cdot 3\end{array}$ & $\begin{array}{r}35 \\
19 \\
9 \\
6 \\
1 \\
8 \\
9 \\
52\end{array}$ & $\begin{array}{r}9 \\
40 \\
23 \\
13 \\
9 \\
40 \\
24 \\
149\end{array}$ & $\begin{array}{l}0 \cdot 25 \\
2 \cdot 1 \\
2 \cdot 5 \\
2 \cdot 1 \\
9 \cdot 0 \\
5 \cdot 0 \\
2 \cdot 6 \\
2 \cdot 9\end{array}$ & $\begin{array}{r}55 \\
23 \\
11 \\
14 \\
4 \\
13 \\
9 \\
74\end{array}$ & $\begin{array}{r}16 \\
47 \\
27 \\
34 \\
12 \\
57 \\
24 \\
201\end{array}$ & $\begin{array}{l}0 \cdot 29 \\
2 \cdot 0 \\
2 \cdot 4 \\
2 \cdot 4 \\
3 \cdot 0 \\
4 \cdot 4 \\
2 \cdot 6 \\
2 \cdot 7\end{array}$ \\
\hline
\end{tabular}

was made to determine whether some specific steps could have been taken to prevent death. The cases were divided into five grades of preventability (table 5). There were considerable differences in the different clinical groups. In 21

Table 5 Possible preventability of death related to category $(A-G)$

\begin{tabular}{|c|c|c|c|c|c|c|}
\hline Category & Inevitable & $\begin{array}{l}\text { Probably } \\
\text { inevitable }\end{array}$ & $\begin{array}{l}\text { Possibly } \\
\text { preventable }\end{array}$ & $\begin{array}{l}\text { Probably } \\
\text { preventable }\end{array}$ & $\begin{array}{l}\text { Don't } \\
\text { know }\end{array}$ & Total \\
\hline $\begin{array}{l}\text { A } \\
\text { B } \\
\text { C } \\
\text { D } \\
\text { E } \\
\text { F } \\
\text { G } \\
\text { Total } \quad \text { B-F }\end{array}$ & 38 & $\begin{array}{r}16 \\
1\end{array}$ & $\begin{array}{r}19 \\
2 \\
2 \\
6 \\
2 \\
29\end{array}$ & $\begin{array}{l}1 \\
6 \\
9\end{array}$ & $\begin{array}{r}1 \\
2 \\
8 \\
14 \\
1 \\
1 \\
7 \\
7 \\
26\end{array}$ & $\begin{array}{r}55 \\
23 \\
11 \\
14 \\
4 \\
13 \\
9 \\
65\end{array}$ \\
\hline
\end{tabular}

of the 23 category $B$ deaths it was felt that intervention could possibly have prevented death whereas in the 14 category $\mathrm{D}$ deaths there was none where intervention might have made a difference. Deaths in categories $E$ and $F$ had a similar pattern to those in category $B$.

When comparing North and Southern Derbyshire (table 6) for adverse social factors it was found that they were absent among the probably inevitable deaths in the same proportion $(81 \%$ and $83 \%)$. Where deaths were categorised as possibly or probably preventable Southern Derbyshire showed a greater proportion with definite adverse factors, $64 \%$ against $36 \%$.

All of the deaths were identified to their local electoral wards and to the Jarman deprivation 
Table 6 Preventability and adverse social factors. Results are number (\%)

\begin{tabular}{lccc}
\hline $\begin{array}{l}\text { Preventability } \\
\text { of death:adverse } \\
\text { social factors }\end{array}$ & $\begin{array}{l}\text { North } \\
\text { Derbyshire }\end{array}$ & $\begin{array}{l}\text { Southern } \\
\text { Derbyshire }\end{array}$ & $\begin{array}{l}\text { North and } \\
\text { Southem } \\
\text { Derbyshire } \\
\text { combined }\end{array}$ \\
\hline $\begin{array}{l}\text { Inevitable/probably inevitable: } \\
\text { Absent }\end{array}$ & $17(81)$ & $29(83)$ & $46(82)$ \\
Possibly & $1(5)$ & $3(9)$ & $4(7)$ \\
Definite & $3(14)$ & $2(6)$ & $5(9)$ \\
Not known & 0 & $1(<3)$ & $1(2)$ \\
Total & $21(100)$ & $35(100)$ & $56(100)$ \\
Probably/possibly preventable: & $2(18)$ & $4(14)$ & $6(15)$ \\
Absent & $4(36)$ & $5(18)$ & $9(23)$ \\
Possibly & $4(36)$ & $18(64)$ & $22(56)$ \\
Definite & $1(>9)$ & $1(4)$ & $2(5)$ \\
Not known & $11(100)$ & $28(100)$ & $39(100)$ \\
Total & & &
\end{tabular}

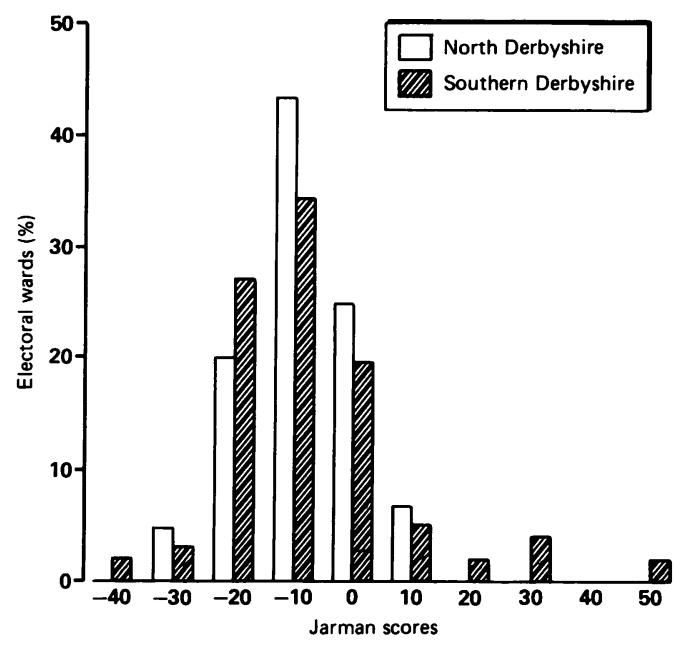

Farman scores for electoral wards in Derbyshire.

indices of the ward. When the distribution of the Jarman scores of the electoral wards of North and Southern Derbyshire are compared (figure) two features are apparent. First, in both health authorities the most prevalent scores are in the range of -10 to 0 and second, Southern Derbyshire contains a wider range of deprivation scores than does North Derbyshire. North Derbyshire contained no electoral wards with Jarman scores over 20 whereas Southern Derbyshire contained eight.

\section{Discussion}

The postperinatal mortality rate is one of a series of indices that a health district uses to assess its performance in the field of child care. The Department of Health has produced a series of performance indicators for districts but does not indicate what deviation from the national average should lead to inquiry and action. ${ }^{4}$ The initiative for this study came from Southern Derbyshire where over a number of years the infant postperinatal mortality rate was significantly higher than the national average and that in North Derbyshire $(p=<0.01)$. In the two years under study the postperinatal death rate in North Derbyshire was $4 \cdot 77 / 1000$ live births and that in Southern Derbyshire was $6 \cdot 1 / 1000$ live births, the one above and the other below the national average.

When the deaths were grouped into those probably not preventable and those possibly preventable after birth, the former rates were remarkably similar in North and Southern Derbyshire, $2 \cdot 16$ and $2 \cdot 3 / 1000$ live births respectively, apparently randomly distributed through North and Southern Derbyshire. This distribution of deaths in the two districts occurred despite all the non-white deaths occurring in Southern Derbyshire. We feel justified in using this group of deaths as controls for the possibly preventable group of deaths where differences in rates occur. The overall differences in the mortality rates in the two districts lay largely in those that we designate category B deaths. The rate of category $B$ deaths in Southern Derbyshire was $1 \cdot 3 / 1000$ live births compared with 0.46 in North Derbyshire. A similar difference is seen in category $C$ but not in categories $\mathrm{D}, \mathrm{E}$, and $\mathrm{F}$. The numbers of cases involved do not make these differences significant. However when we analysed the deaths in category A compared with those from all other categories from the point of view of the presence or absence of 34 adverse factors, considerable differences were noted.

A very wide range of factors was found (table 3). The overall adverse factor/case ratios were similar between North and Southern Derbyshire. Different categories of deaths have different ratios. In the category $A$ deaths there were only 0.29 factors/case $(0.35$ in the north and 0.25 in the south). All of the other categories showed more than two adverse factors/case, the highest being category $F$ with 4.4 followed by $E$ with three. The numbers of adverse social factors gives only one side of the picture. The presence of factors has to be related to the individual death and this can only be undertaken by a complete confidential inquiry.

Since the Court report ${ }^{5}$ there have been a number of studies suggesting that child mortality is related to many factors ${ }^{6-9}$ and studies of child deaths support this. ${ }^{10} 11$ The confidential inquiries often revealed features and incidents where incidents leading to probable intervention could have taken place. These points of intervention have already led to local action. Individual cases are not reported at length here as many could be identifiable but details of some have been reported elsewhere. 12

When we looked at the distribution of the Jarman scores of all wards in North and Southern Derbyshire there were no wards in North Derbyshire with a Jarman score of over 20 and we were able to correlate the areas of high mortality with the Jarman score. ${ }^{13}$ This information helps those who can use the Jarman score to direct general family care, but the factors that go to the production of this score are not themselves the direct causes of the deaths ${ }^{1415}$ and the latter are only available through the confidential inquiries.

The evidence we have obtained suggests that there are different levels of preventability in the different clinicopathological groupings within the infants presenting as unexpected deaths (table 5). The most striking feature was that the group which revealed no preventable deaths was that showing non-significant pathology (category D), what may be termed 'true sudden 
infant death', and that this showed similar rates in North and Southern Derbyshire. The categories that showed the greatest number of possibly preventable deaths were the $B, E$, and F. Those in category $B$ are deaths where treatable factors are present and these constitute the group of the cot deaths where prevention is, with our present knowledge, most practicable and is the group that largely explained the different death rates in North and Southern Derbyshire.

The category $\mathbf{E}$ and $\mathbf{F}$ deaths are the most controversial but as they constituted over $10 \%$ of the deaths in this study they need comment. The preventable factors identified in these families are those associated more with the work of social services than with health services. In the population of Southern Derbyshire a high rate of cot death has been demonstrated in the siblings of families on the child abuse register. ${ }^{16}$ Their identification and prevention would seem to lie in the field of child abuse. This needs further study.

This project set out to use confidential case studies to determine factors to explain the continued higher postperinatal mortality rate in Southern compared with North Derbyshire. It was found that there was no difference in the rates of the inevitable deaths in the two districts or in the rate of completely unexplained cot deaths. The differences lay in the partially explained cot deaths (categories B and C). Any attempt to reduce postperinatal mortality in Southern Derbyshire needs immediate focus on these two categories of death.

This study pre-empted the Department of Health recommendation for confidential inquiry and demonstrates the use of such inquiries. ${ }^{17}$ It also supplies supplementary information that is necessary for taking action on information such as that presented by Pharoah and Alberman. ${ }^{18}$

The use of the confidential inquiry has been of such local benefit, both in identifying the areas where possible prevention of death lies and in providing sites of action, that it is being continued in Southern Derbyshire as part of the community child care audit.

1 Trent Regional Health Authority. Trent perinatal/infant mortality study 1983/85. Sheffield: Trent Area Health Authority, 1986

2 Taylor EM, Emery JL. Two year study of the causes of postperinatal deaths classified in terms of preventability. Arch Dis Child 1982;57:668-73.

3 Taylor EM, Emery JL. Categories of preventable unexpected infant deaths. Arch Dis Child 1990;65:535-9.

4 Department of Health. Comparing health authorities health services indicators 1983-86. London: DHSS, 1988.

5 Committee on Child Health Services. Fit for the future. London: HMSO, 1976. (Court report.) (Cmnd 6680.)

6 Department of Health and Social Security. Inequalities in health: report of a research working group. London: DHSS, 1980.

7 Smith GD, Bartley M, Blane D. Black report on socioeconomic irregularities in health 10 years on. BMF 1990; 301:373-7.

8 Smith T. Poverty and health in the 1990s. [Editorial.] $B M F$ 1990;301:349-50.

9 Main JA, Main PGN. The Black report. BMf 1990;301:608.

10 Watson E. An epidemiological and sociological study of unexpected death in infancy in 9 areas of southern England Med Sci Law 1981;21:99-104.

11 Rao M, Hoinville E. Review of post perinatal mortality in a health district with a garrison town. $B M \mathcal{F}$ 1988;297:662.

12 Newlands M. A study of postperinatal deaths in Southem Derbyshire. Glasgow: University of Glasgow, 1991. (MD thesis.)

13 Jarman B. Identification of underprivileged areas. $B M F$ 1983;286:1705-9.

14 Smith GD. Second thoughts on the Jarman index. [Editorial.] $B M \mathcal{F}$ 1991;302:359-60.

15 Talbot RJ. Underprivileged areas and health care planning: implications of use of Jarman indicators of urban deprivation. implications of use of Ja

16 Newlands M, Emery JL. Child abuse and cot death. Child Abuse Negl 1991;15:275-8.

17 Department of Health. Perinatal neonatal and infant mortality. London: HMSO, 1988. Government reply to the firs report from the Social Services Committee Session 1988-89.

18 Pharoah POD, Alberman ED. Annual statistical review. Arch Dis Child 1990;65:147-51. 